\title{
EFFECTS OF HEMOTOXIC SNAKE BITE ENVENOMATION ON HAEMATOLOGICAL PARAMETERS VARIABILITY IN PREDICTING COMPLICATIONS
}

\author{
M.P. Harikrishnan, *C.R. Anil Kumar, M.K. Anand, J. Earali \\ JUBILEE MISSION MEDICAL COLLEGE AND RESEARCH INSTITUTE, THRISSUR, INDIA
}

Background. Snake bite envenomation is a major public health problem in India with a high mortality rate. The major complications following a hemotoxic snake bite are disseminated intravascular coagulation (DIC), shock, acute kidney injury (AKI), acute respiratory distress syndrome (ARDS) and coagulopathy. The study explores a possible correlation of the haematological parameters studied to complications like DIC, AKI, acute renal failure (ARF), ARDS, shock and gastrointestinal (GI) bleed.

Objective. The aim of the study was to find out the effect of snakebite envenomation on the major haematological parameters of the body in relation to complications.

Methods. This cross-sectional study was conducted during a period of 18 months. 150 patients were included in the study after obtaining their informed consents. Data collection was done using a proforma. The study also compared clotting time (CT) by capillary tube method and whole blood clotting time at 20 minutes (WBCT20). SPSS software was used for statistical analysis.

Results. Among the people with complications, the majority (52\%) of participants had AKI, 26\% of them requiring dialysis, $16.7 \%$ participants had GI bleed, $11.3 \%$ participants had shock and 10\% participants had DIC.

Conclusions. A prolonged bleeding time was found to be one of the most helpful haematological parameters in predicting shock and AKI. Clotting time by both capillary tube and WBCT20 methods were comparable in predicting complications.

KEYWORDS: hemotoxic snake bite; acute kidney injury; shock; clotting time; bleeding time.

\section{Introduction}

Snakebite envenomation is a major public health problem in India with a high mortality rate [1]. The WHO estimates that there are 81000 snake envenomation in India per annum with a mortality of $11000(13.5 \%)$ [2]. It has been reported that there are 5 million snake bites with 2.5 million envenomation and 125,000 fatalities worldwide annually [3]. India is reported to have the highest number of snake bites $(81,000)$ and deaths $(11,000)$ per year [3]. Snakebite is considered as one of the neglected tropical diseases by the WHO [4]. The mortality due to snakebites in India is due to various socioeconomic, cultural and environmental causes [5]. Among the 52 species of venomous snakes in India, 4 species are responsible for greatest number of snake bites which are medically significant. These are referred to as the big four, Bungarus caeruleus (common krait), Daboia russelii (Russel's viper), Echis carinatus (saw scaled viper), Naja naja (Indian cobra). But recently it has been discovered that another species, the hump-pit viper (Hypnale

*Corresponding author: Anil Kumar CR, Associate Professor, Jubilee Mission Medical College and Research Institute, Thrissur, 680005, India. E-mail: anilkumarcr3005@gmail.com hypnale), is capable of causing lethal envenomation [6].

The venomous snakes found in India can be classified per the type and action of venom as Neurotoxic (Cobra, Krait) and Hemotoxic (Vipers). Then main complaints are pain and swelling at the site of snake bite [7-11].

The major complications following hemotoxic snake bite are disseminated intravascular coagulation (DIC), shock, acute kidney injury (AKI), acute respiratory distress syndrome (ARDS) and coagulopathy [12]. AKI is one of the serious complications developing after snake bite $[13,14]$. Early identification of hemotoxic envenomation and anti-snake venom (ASV) administration may help decrease morbidity and mortality [15].

The study tries to find out the common complications after hemotoxic snake bites and to explore a possible correlation of the haematological parameters to complications. The study also compares clotting time by capillary tube method and WBCT20. ASV administration is currently based on prolongation of WBCT20. Capillary tube method for estimating CT could be used in a resource poor setting, if the 
predictability of the test is comparable to that of WBCT20. In a study by Ratnayake et al [16] the diagnostic utility of WBCT20 was determined at the time of admission and it was found out that it had got sensitivity of $82 \%$ and specificity of $98 \%$ in detecting venom induced consumption coagulopathy (VICC). The aim of the study was to assess the value of haematological parameters, i.e. bleeding time (BT), clotting time $(\mathrm{CT})$, prothrombin time (PT), activated partial thromboplastin time (aPTT) in predicting the complications. The primary objective was to assess the effect of snake bite on the major haematological parameters of the body in relation to complications.

\section{Methods}

This cross-sectional study was conducted over a period of 18 months after obtaining clearance from the institutional ethics committee. A total of 150 patients, who were above 18 years of age, had given written informed consent and had clinical features of hemotoxic envenomation or increase of any of the evaluated haematological parameters as bleeding time (BT), clotting time (CT), prothrombin time (PT), activated partial thromboplastin time (aPTT), were included in the study. Convenient sampling was done.

The patients who had not given written informed consent and the patients with bites other than hemotoxic snakebites were excluded from the study. Any patient who is a known case of bleeding disorder, chronic alcoholic, with acute or chronic liver disease, pregnant females and on anticoagulation therapy were excluded from the current study. After admission a complete history was taken and a thorough clinical examination was conducted. As per the protocol followed in our Institute, all patients bitten by poisonous snakes received polyvalent anti snake venom (ASV), within 15 minutes of reaching the hospital, provided they had clinical features of envenomation. The patients with no initial features of envenomation were administered with ASV as soon as they exhibited first signs of envenomation.

Initial blood samples collected from the patients admitted with hemotoxic envenomation were sent for complete hemogram, random blood sugar (RBS), renal function tests (RFT), liver function tests (LFT), serum electrolytes and important coagulation parameters including BT, CT (both WBCT20 and capillary tube methods), PT with INR, D-dimer and a PTT. All patients with features of envenomation were administered with 10 vials of ASV. The response was monitored clinically by doing WBCT20 and Clotting Time (CT) using the capillary tube method, with 2 hour intervals if prolonged initially, otherwise with 6 hour intervals.

If the features of envenomation were persistent or if the WBCT20 was prolonged after 6 hours of first dose, a repeated dose of 10 vials of ASV was given. Blood parameters like BT, CT, PT, APTT and D-dimer were investigated as per the protocol. The first sample of blood was taken on admission for evaluating BT, CT, PT with INR, and APTT. BT was subsequently estimated 2 times with a 5 minute interval, then in 2 hours, 4 hours, and 6 hours after admission. Then every 6 hours if prolonged. Once normal, it was repeated once daily. CT was estimated at time of admission. If in norm, CT was repeated with 6 hour intervals for 1 day to test for requirement of ASV. If prolonged, it was tested with 2 hour intervals till the normal rate. CT was estimated by 20-minute whole blood clotting method (WBCT20) and capillary tube method for comparison study. APTT was done on the $1^{\text {st }}$ day and $7^{\text {th }}$ day, but PT was done at the time of admission and daily. D-dimer was done when there was prolongation of CT on 3 consecutive occasions. ASV was given according to the standard protocol with administration of ASV every 6 hours till normal coagulation profile.

A bite was considered hemotoxic, if the culprit snake is identified as hemotoxic or by coagulopathy as suggested by haematological parameters. AKI was defined as the increase of serum creatinine $\geq 0.3 \mathrm{mg} / \mathrm{dL}$ within 48 hours or increase in serum creatininein $\geq 1.5$ times from baseline. AKI staging was performed according to the "Kidney Disease: improving global outcomes" (KDIGO) clinical practice guidelines [17]. Shock was defined by a systolic blood pressure of $<90 \mathrm{mmHg}$ with evidence of tissue hypoperfusion $(<0.5 \mathrm{~mL} / \mathrm{kg} / \mathrm{h}$ decrease in urine output, cold skin, and or requiring inotropic drugs). The data was collected, occurrence of complications and derangement in haematological parameters were studied and analysed. The data collected was recorded in a standard data collection sheet as per study proforma and later transferred to Microsoft Excel spread sheet for statistical analysis. Complications like AKI, shock were considered as primary outcome variables. CT by capillary tube and WBCT20 at different time periods, BT, PT, aPTT etc. were considered as explanatory variables. 
Descriptive analysis was carried out by frequency and proportion for categorical variables. Categorical outcomes were compared between the study groups using the Chi square test / the Fisher's Exact test (if the overall sample size was $<20$ or if the expected number in any one of the cells was $<5$, Fisher's exact test was used). $P$ value $<0.05$ was considered statistically significant. IBM SPSS version 22 was used for statistical analysis [18].

\section{Results}

In the study it was observed that the snake bites were more common in males. Out of 150 subjects in our study, $24(16.0 \%)$ cases, were bites by Russel's viper, 4 (2.7\%) cases by krait, $2(1.3 \%)$ cases by hump nosed pit viper and 120 $(80.0 \%)$ were unidentified. The patients included in the study, who had any comorbidity, accounted for $36.0 \%$ of the study population (Table 1).
Among the complications, the majority (52\%) of participants had AKI, $26 \%$ of them required dialysis; $16.7 \%$ participants had GI bleed; $11.3 \%$ participants had shock and $10 \%$ participants had DIC (Table 2).

Association between AKI and shock with various parameters have been shown in the Table below (Table 3). At the time of admission, 11 patients $(47.8 \%)$ presenting with AKI reported prolonged CT (capillary tube). However, in 6 hours $22(100 \%)$ participants with prolonged CT had AKI. A majority of $36(60 \%)$ participants reported AKI with normal WBCT20 at the time of admission. The occurrence of AKI was evidenced in $30(81 \%)$ participants with prolonged WBCT20 in 6 hours. The occurrence of AKI was found in 17 (58.6\%) participants with PT >16.50 seconds. All participants with APTT $>35$ reported AKI (Table 3). WBCT20 and CT by capillary tube method in 6 hours were comparable in predicting AKI.

Table 1. Summary of baseline parameters in study population $(n=150)$

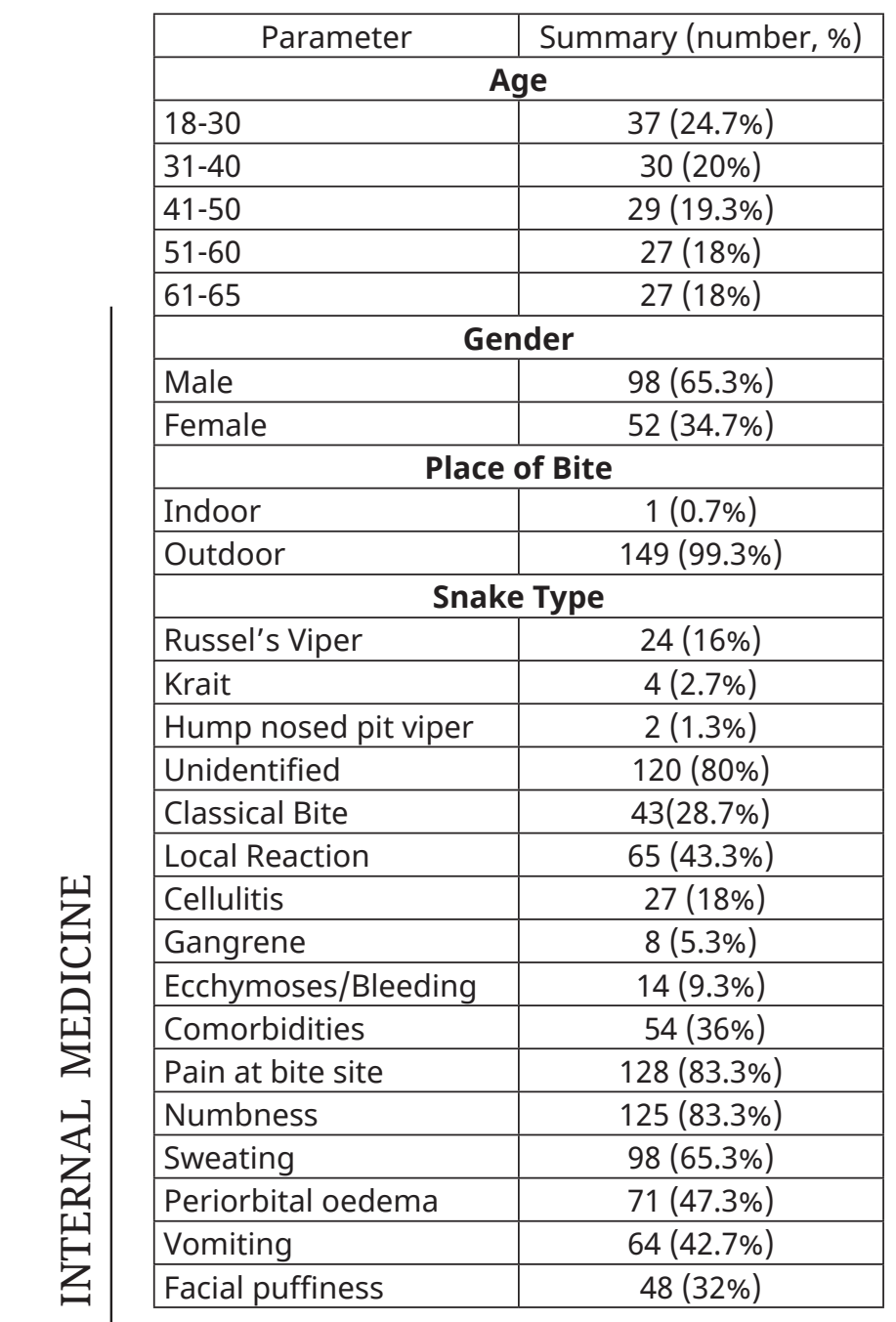

\begin{tabular}{|c|c|}
\hline Parameter & Summary (number, \%) \\
\hline Abdominal pain & $45(30 \%)$ \\
\hline Neurological signs & $28(18.7 \%)$ \\
\hline Respiratory distress & $25(16.7 \%)$ \\
\hline Low back ache & $20(13.3 \%)$ \\
\hline Bleeding from any site & $15(10 \%)$ \\
\hline Respiratory failure & $15(10 \%)$ \\
\hline ARDS & $11(7.3 \%)$ \\
\hline Hematemesis & $4(2.7 \%)$ \\
\hline \multicolumn{2}{|c|}{ Comorbidities } \\
\hline Diabetes Mellitus & $25(16.7 \%)$ \\
\hline Hypertension & $24(16 \%)$ \\
\hline $\begin{array}{l}\text { Ischemic Heart } \\
\text { Disease }\end{array}$ & $0(0 \%)$ \\
\hline Respiratory Failure & $0(0 \%)$ \\
\hline Bronchial Asthma & $11(7.3 \%)$ \\
\hline $\begin{array}{l}\text { Chronic Obstructive } \\
\text { Lung Disease }\end{array}$ & $23(15.3 \%)$ \\
\hline \multicolumn{2}{|c|}{ CT prolonged } \\
\hline At the Time of admission & $23(15.3 \%)$ \\
\hline 2 Hours & $36(24 \%)$ \\
\hline 4 Hours & $29(19.3 \%)$ \\
\hline 6 Hours-12 hours & $49(32.03 \%)$ \\
\hline Day 2 & $4(2.7 \%)$ \\
\hline \multicolumn{2}{|c|}{ WBC T20-Prolonged } \\
\hline At the time of admission & $90(60 \%)$ \\
\hline 2 Hours & $61(40.7 \%)$ \\
\hline 4 Hours & $48(32 \%)$ \\
\hline 6 Hours -12 hours & $86(57.3 \%)$ \\
\hline Day 2 & $15(10 \%)$ \\
\hline
\end{tabular}


Table 2. Summary of the complications observed ( $N=150)$

\begin{tabular}{|l|c|}
\hline \multicolumn{1}{|c|}{ Complications } & Summary (number, \%) \\
\hline AKI & $78(52 \%)$ \\
\hline Acute Renal Failure (AKI requiring dialysis) & $39(26 \%)$ \\
\hline Dialysis done & $39(26 \%)$ \\
\hline GI Bleed & $25(16.7 \%)$ \\
\hline Shock & $17(11.3 \%)$ \\
\hline DIC & $15(10 \%)$ \\
\hline ARDS & $11(7.3 \%)$ \\
\hline Reaction to ASV & $6(4 \%)$ \\
\hline Mortality & $2(1.3 \%)$ \\
\hline Intra Cerebral Bleed & $0(0 \%)$ \\
\hline Hypopituitarism & $0(0 \%)$ \\
\hline Guillain Barre Syndrome & $0(0 \%)$ \\
\hline Peripheral Neuropathy & $0(0 \%)$ \\
\hline
\end{tabular}

Table 3. Association of different parameters with AKI

\begin{tabular}{|c|c|c|c|}
\hline \multirow{2}{*}{ Parameter } & \multicolumn{2}{|c|}{ AKI } & \multirow{2}{*}{ P Value } \\
\hline & Present & Absent & \\
\hline \multicolumn{4}{|c|}{ CT capillary tube at the time of admission } \\
\hline Prolonged $(\mathrm{N}=23)$ & $11(47.8 \%)$ & $12(52.2 \%)$ & \multirow{2}{*}{0.663} \\
\hline Normal $(\mathrm{N}=127)$ & $67(52.8 \%)$ & $60(47.2 \%)$ & \\
\hline \multicolumn{4}{|c|}{ CT capillary tube in 6 hours } \\
\hline Prolonged $(\mathrm{N}=22)$ & $22(100 \%)$ & $0(0 \%)$ & \multirow{2}{*}{ * } \\
\hline Normal $(\mathrm{N}=120)$ & $48(40 \%)$ & $72(60 \%)$ & \\
\hline \multicolumn{4}{|c|}{ WBCT20 at admission } \\
\hline Prolonged $(\mathrm{N}=90)$ & $42(46.7 \%)$ & $48(53.3 \%)$ & \multirow{2}{*}{0.109} \\
\hline Normal $(\mathrm{N}=60)$ & $36(60 \%)$ & $24(40 \%)$ & \\
\hline \multicolumn{4}{|c|}{ WBCT20 at 6 hours } \\
\hline Prolonged $(\mathrm{N}=37)$ & $30(81 \%)$ & $7(19 \%)$ & \multirow{2}{*}{$<0.001$} \\
\hline Normal $(\mathrm{N}=105)$ & $40(38 \%)$ & $65(62 \%)$ & \\
\hline \multicolumn{4}{|c|}{ BT } \\
\hline$>7(\mathrm{~N}=12)$ & $12(100 \%)$ & $0(0 \%)$ & \multirow{2}{*}{ * } \\
\hline$\leq 7(\mathrm{~N}=138)$ & $66(47.8 \%)$ & $72(52.2 \%)$ & \\
\hline \multicolumn{4}{|c|}{ PT } \\
\hline$>16.50(\mathrm{~N}=29)$ & $17(58.6 \%)$ & $12(41.4 \%)$ & \multirow{2}{*}{0.319} \\
\hline$\leq 16.50(\mathrm{~N}=116)$ & $56(48.3 \%)$ & $60(51.7 \%)$ & \\
\hline \multicolumn{4}{|c|}{ APTT } \\
\hline$>35(N=23)$ & $23(100 \%)$ & $0(0 \%)$ & \multirow{2}{*}{ * } \\
\hline$\leq 35(\mathrm{~N}=123)$ & $51(41.5 \%)$ & $72(58.5 \%)$ & \\
\hline
\end{tabular}

*No statistical tests were applied due to 0 values in one of the cells.

The occurrence of shock was found in 6 (26.1\%) participants with prolonged CT at the time of admission (P value of 0.039). However, 11 (50\%) participants had shock with prolonged $C T$ in 6 hours ( $P$ value $<0.001$ ). The occurrence of shock was found in 11 (12.2\%) participants with normal WBCT20 at admission. 17 (42\%) participants with prolonged WBC T20 in 6 hours reported shock. The occurrence of shock was found to be statistically significant with $p$ value of $<0.001$ and the proportion of shock was 8 $(66.7 \%)$ with BT $>7$ seconds. The occurrence of shock was found to be significant with a P value of $<0.001$ in $7(30.4 \%)$ participants with $>35$ APTT (Table 4). 
Table 4. Association of different parameters with shock

\begin{tabular}{|c|c|c|c|}
\hline \multirow{2}{*}{ Parameter } & \multicolumn{2}{|c|}{ Shock } & \multirow{2}{*}{ P Value } \\
\hline & Present & Absent & \\
\hline \multicolumn{4}{|c|}{ CT capillary tube at the time of admission } \\
\hline Prolonged $(\mathrm{N}=23)$ & $6(26.1 \%)$ & $17(73.9 \%)$ & \multirow{2}{*}{0.039} \\
\hline Normal $(\mathrm{N}=127)$ & $11(8.7 \%)$ & $116(91.3 \%)$ & \\
\hline \multicolumn{4}{|c|}{ CT capillary tube at 6 Hours } \\
\hline Prolonged $(\mathrm{N}=22)$ & $11(50 \%)$ & $11(50 \%)$ & \multirow{2}{*}{$<0.001$} \\
\hline Normal $(\mathrm{N}=120)$ & $6(5 \%)$ & $114(95 \%)$ & \\
\hline \multicolumn{4}{|c|}{ WBCT20 at Admission } \\
\hline Prolonged $(\mathrm{N}=90)$ & $11(12.2 \%)$ & $79(87.8 \%)$ & \multirow{2}{*}{0.875} \\
\hline Normal $(\mathrm{N}=60)$ & $6(10 \%)$ & $54(90 \%)$ & \\
\hline \multicolumn{4}{|c|}{ WBCT20 at 6 Hours } \\
\hline Prolonged $(\mathrm{N}=37)$ & $17(46 \%)$ & $20(54 \%)$ & \multirow{2}{*}{ * } \\
\hline Normal $(\mathrm{N}=105)$ & $0(0 \%)$ & $105(100 \%)$ & \\
\hline \multicolumn{4}{|c|}{ BT } \\
\hline$>7(\mathrm{~N}=12)$ & $8(66.7 \%)$ & $4(33.3 \%)$ & \multirow{2}{*}{$<0.001$} \\
\hline$\leq 7(\mathrm{~N}=138)$ & $9(6.5 \%)$ & $129(93.5 \%)$ & \\
\hline \multicolumn{4}{|c|}{ PT } \\
\hline$>16.50(\mathrm{~N}=29)$ & $12(41.4 \%)$ & $17(58.6 \%)$ & \multirow{2}{*}{ * } \\
\hline$\leq 16.50(\mathrm{~N}=116)$ & $0(0 \%)$ & $116(100 \%)$ & \\
\hline \multicolumn{4}{|c|}{ APTT } \\
\hline$>35(\mathrm{~N}=23)$ & $7(30.4 \%)$ & $16(69.6 \%)$ & \multirow{2}{*}{$<0.001$} \\
\hline$\leq 35(\mathrm{~N}=123)$ & $6(4.9 \%)$ & $117(95.1 \%)$ & \\
\hline
\end{tabular}

*No statistical tests were applied due to 0 values in one of the cells.

\section{Discussion}

In this study, shock was seen in $11.3 \%$ of the total cases, AKI in $52 \%$, ARF (AKI requiring dialysis) in $26 \%$ and gastro intestinal bleed in $16.7 \%$. A comparatively higher incidence of shock was reported by Harshavardhan et al. [19] in their study on hemotoxic snake bite cases $(36 \%)$. But a comparable value $(10.38 \%)$ to our study was reported by Kumar et al. [20].

Acute kidney injury (AKI) was established in $52 \%$ of the cases in the present study. A somewhat similar value was observed $(30.71 \%)$ in a previous study [21]. Bhalla et al studied the clinical profile of snake bite in a tertiary centre and observed AKI in $47.6 \%$ of the cases [22]. Similar study on outcomes of snakebite poisoning in a tertiary centre by Meenakshi B et al. reported AKI in $44 \%$ of cases.

Proteins are an important constituent of snake venoms and they are encoded by polyadenylated mRNA in the venomous glands (12S and 20S) [21]. Besides proteins, the other components present in snake venom include lipids, polysaccharides, nucleotides, nucleosides, free amino acids, riboflavin, serotonin and histamine. Pharmacologically active substances of the venom are enzymes and low molecular weight peptides. The main sites of action of these enzymes are cell membranes, the vascular wall and the blood coagulation cascade $[20,22]$. Snake venom, mainly those of Viperidae, contain also molecules that act on the four interconnected blood systems (i) the coagulation system, (ii) fibrinolytic system, (iii) complement and (iv) the kinin system [22].

Shock is consistently the single most important factor in mortality due to Indian viper bite poisoning. The pattern of shock observed shows early transient shock, early sustained shock and late onset shock. Shock is caused by reduction in the circulating blood volume due to a venom-mediated generalized increase in endothelial permeability. Apart from this, massive limb oedema can lead to considerable compartmentalization of blood and plasma. Pulmonary intravascular coagulation, pulmonary oedema caused by increased pulmonary vascular permeability, and cardiotoxic effects of the venom may also be contributory.

The kidney is a highly vascularized organ with excretory function, so it is prone to venom toxicity. AKI, the most significant of all the renal 
manifestations, has been reported to be of varying frequency in different studies [23]. Many studies have appeared in literature on snake bite-induced AKI over a decade. Phospholipase A2 is the most widespread and extensively studied of all venom enzymes. It damages mitochondria, red blood cells, leucocytes, platelets, skeletal muscle, vascular endothelium, and other membranes and leads to auto pharmacological release of histamine and anti-coagulants. Viper bites cause various systemic symptoms such as coagulopathy, haemolysis, AKI, a generalized increase in capillary permeability and rhabdomyolysis [23]. Haemoglobinuria caused by intra-vascular haemolysis and myoglobinuria resulting from rhabdomyolysis contributes to development of AKI. Haemorrhage, hypotension, disseminated intravascular coagulation, intravascular haemolysis, and rhabdomyolysis enhance renal ischemia leading to renal failure. Enzymatic activities of snake venoms account for direct nephrotoxicity and immunologic mechanism is insignificant [24].

A variety of factors contribute to shock like fright, hypovolemia (due to extravasation of fluids and blood loss), myocardial depression, haemorrhage into the adrenals and pituitary.

\section{Conclusions}

A prolonged clotting time as obtained by capillary tube method in 6 hours is helpful in predicting development of shock. However, since AKI occurred even in those patients having normal clotting time and WBCT20, these parameters may not be useful as predictors of AKI. Prolonged CT by capillary tube method and WBCT20 in 6 hours were comparable in predicting AKI. Prolongation of more than 16.5 seconds in prothrombin time was helpful in predicting the development of shock. However prolonged prothrombin time (>16.50) was not useful in predicting AKI. A prolonged APTT more than 35 seconds was helpful in predicting the onset of shock and AKI. A prolonged bleeding time was found to be one of the most helpful haematological parameters in predicting shock and AKI.

\section{Limitations of the study}

A comparatively low number of 150 cases may have strained the generalizations derived by the study. Parameters like CT by capillary tube method did not have a control test measured in patients with non-poisonous snake bite envenomation. A degree of individual variability was inevitable in the evaluation of $C T$ both by capillary tube and WBCT20 methods as well as that of BT. The duration of envenomation prior to admission has not been taken into account in this study, possibly affecting the correlation between haematological parameters and development of complications.

\section{Conflicts of Interest}

Authors declare no conflict of interest.

\section{Authors' Contributions}

Harikrishnan M.P. - data curation; investigation; methodology; supervision; writing original draft; writing - review \& editing.

Anil Kumar C.R. - data curation; investigation; supervision; project administration; methodology; supervision; writing - original draft; writing - review \& editing.

Anand M.K. - data curation; investigation; methodology; supervision; writing - original draft; writing - review \& editing.

Jerry Earali - data curation; investigation; methodology; supervision; writing - original draft; writing - review \& editing.

\section{ВАРІАБЕЛЬНІСТЬ ГЕМАТОЛОГІЧНИХ ПАРАМЕТРІВ ЯК ПРЕДИКТОР РОЗВИТКУ УСКЛАДНЕНЬ ПІСЛЯ ПОТРАПЛЯННЯ В ОРГАНІЗМ ГЕМОТОКСИЧНОЇ ОТРУТИ ВНАСЛІДОК УКУСУ ЗМІї}

M.P. Harikrishnan, *C.R. Anil Kumar, M.K. Anand, Jerry Earali JUBILEE MISSION MEDICAL COLLEGE AND RESEARCH INSTITUTE, THRISSUR, INDIA

\footnotetext{
Вступ. Одна з найбільших проблем закладів охорони здоров'я в Індії - укуси змій, які супроводжуються високою летальністю. Найбільш часті ускладнення, які розвиваються внаслідок потрапляння в організм гемотоксичної зміїної отрути, че синдром дисемінованого внутрішньосудинного згортання (ДВЗ), шок, гостре ураження нирок (ГУН), гострий респіраторний дистрес синдром (ГРДС) та кооагулопатія.
} 
Мета дослідження - дослідити можливий взаємозв'язок між частотою розвитку ускладнень як ДВЗ, ГУН, гостра ниркова недостатність (ГНН), ГРДС, шок та кишково-шлункові кровотечі.

Методи. Це перехресне дослідення проводилося впродовж 18 місяців. Було залучено 150 пацієнтів, які підписали поінформовану згоду. Збір даних проводили за допомогою спеціально розробленої форми. Також досліджували швидкість згортання крові за допомогою капіляра та 20-хвилинного тесту на згортання цільної крові (англ. 20WBCT, показники коагулограми. Для статистичної обробки отриманих даних використовували програмне забезпечення IBM SPSS Statistics.

Результати. Серед покусаних людей, уяких розвинулися ускладнення, у більшості (52\%) розвинулося ГУН, внаслідок чого 26\% серед них потребували діалізу, у 16,7\% учасників дослідження були кишковошлункові кровотечі, у 11,3\% - розвинувся шок, у 10\% розвинувся ДВз.

Висновки. Серед досліджуваних гематологічних параметрів для прогнозування розвитку ускладнень (гострого ураження нирок та шоку) після укусу змії найбільш інформативними був подовжений час згортання крові. Обидва методи дослідження згортання крові і за допомогою капіляра і WBCT20 були релевантні та корелювали при прогнозуванні ускладнень.

КЛЮчОВІ СЛОВА: гемотоксична зміїна отрута; укус змії; гостре ураження нирок; шок; час згортання крові; час кровотечі.

\section{Information about the authors}

Harikrishnan M.P. - Senior Resident, MD General Medicine, Department of Medicine, Jubilee Mission Medical College and Research Institute, Thrissur.

ORCID: 0000-0003=3452-5588 email: harikrishnapuram@gmail.com

Anil Kumar C.R. - MD General Medicine, Associate Professor, Department of Medicine, Jubilee Mission Medical College and Research Institute, Thrissur.

ORCID: 0000-0002-6397-2005 email: anilkumarcr3005@gmail.com

Anand M.K. - MD General Medicine, Assistant Professor, Department of Medicine, Jubilee Mission Medical College and Research Institute, Thrissur.

ORCID: 0000-0002-0164-8402 email: anandmk92@yahoo.in

Jerry Earali - MD General Medicine, Professor, Department of Medicine, Jubilee Mission Medical College and Research Institute, Thrissur.

ORCID: 0000-0003-2880-1259 email: jeyearali@gmail.com

\section{References}

1. Dandona R, Kumar GA, Kharyal A, George S, Akbar M, Dandona L. Mortality due to snakebite and other venomous animals in the Indian state of Bihar: Findings from a representative mortality study. PLoS One 2018;13:e0198900. 0198900.

DOI: https://doi.org/10.1371/journal.pone.

2. Kasturiratne A, Wickremasinghe AR, De Silva N, Gunawardena NK, Pathmeswaran A, Premaratna R, et al. The global burden of snakebite: A literature analysis and modelling based on regional estimates of envenoming and deaths. PLoS Med 2008;5:1591604.

DOI: https://doi.org/10.1371/journal.pmed. 0050218

3. Menon JC, Joseph JK. Complications of hemotoxic snakebite in India. Toxinology Clin Toxinology Asia Pacific Africa 2015;35:209-32.

DOI: https://doi.org/10.1007/978-94-007-63869_22.

4. Kasturiratne A, Wickremasinghe AR, de Silva NG, NK, Pathmeswaran A, Premaratna R, Savioli L, Lalloo DG D, HJ. S. The global burden of snakebite: a literature analysis and modelling based on regional estimates of envenoming and deaths. PLoS Med 2008;5:e218.

DOI: https://doi.org/10.1371.

5.Menon J, Joseph JK, Kulkarni K. Treatment of snakebites - a resumé. Cobra 2007;1:1-21.

6. Chippaux JP. Snake-bites: Appraisal of the global situation. Bull World Health Organ 1998;76: 515-24.

7. Lavonas EJ, Gerardo CJ, O'Malley G, Arnold TC, Bush SP, Banner W, et al. Initial Experience with Crotalidae Polyvalent Immune Fab (Ovine) Antivenom in the Treatment of Copperhead Snakebite. Ann Emerg Med 2004;43:200-6.

DOI: https://doi.org/10.1016/j.annemergmed. 2003.08.009.

8. Yin S, Kokko J, Lavonas E, Mlynarchek $S$, Bogdan G, Schaeffer T. Factors associated with difficulty achieving initial control with Crotalidae polyvalent immune fab antivenom in snakebite patients. Acad Emerg Med 2011;18:46-52.

DOI: https://doi.org/10.1111/j.1553-2712. 2010.00958.x.

9. Gerardo CJ, Evans CS, Kuchibhatla M, Drake WG, Mando-Vandrick JD, Yen M, et al. Time to Antivenom 
Administration in Snakebite. Ann Emerg Med 2013; 62:S44.

DOI: https://doi.org/10.1016/j.annemergmed. 2013.07.403.

10. Lavonas EJ, Kerns WP, Gerardo CJ, Richardson W, Whitlow K, Berkoff DJ. 328: Long-Term Limb Function Outcomes Following Copperhead Snakebite. Ann Emerg Med 2008;52:S141-2.

DOI: https://doi.org/10.1016/j.annemergmed. 2008.06.354.

11. Thorson A, Lavonas EJ, Rouse AM, Kerns WP. Copperhead envenomations in the Carolinas. J Toxicol - Clin Toxicol 2003;41:29-35.

DOI: https://doi.org/10.1081/CLT-120018268.

12. Knudsen C, Laustsen $A H$. Recent advances in next generation snakebite antivenoms. Trop Med Infect Dis 2018;3.

DOI: https://doi.org/10.3390/tropicalmed3020042.

13. Kanjanabuch T, Sitprija V. Snakebite Nephrotoxicity in Asia. Semin Nephrol 2008;28:363-72.

DOI: https://doi.org/10.1016/j.semnephrol. 2008.04.005.

14. Chugh KS. Snake-bite-induced acute renal failure in India. Kidney Int 1989;35:891-907.

DOI: https://doi.org/10.1038/ki.1989.70.

15. Greene S, Bush SP. What percentage of snake species are venomous? Medscape 2020.

https://www.medscape.com/answers/ 16882839085/what-percentage-of-snake-species-are-venomou (accessed March 18, 2020).

16. Ratnayake I, Shihana F, Dissanayake DM, Buckley NA, Maduwage K, Isbister GK. Performance of the 20-minute whole blood clotting test in detecting venom induced consumption coagulopathy from Russell's viper (Daboia russelii) bites. Thromb Haemost 2017; 117:500-7.

DOI: https://doi.org/10.1160/TH16-10-0769.

17. Palevsky PM, Liu KD, Brophy PD, Chawla LS, Parikh CR, Thakar CV, et al. KDOQI US commentary on the 2012 KDIGO clinical practice guideline for acute kidney injury. Am J Kidney Dis. 2013;61:649-72.

DOI: https://doi.org/10.1053/j.ajkd.2013.02.349.
18. IBM Corp. Released 2013. IBM SPSS Statistics for Windows, Version 22.0. Armonk, NY: IBM Corp n.d.

19. Harshavardhan L, Lokesh AJ, Tejeshwari HL, Halesha BR, Metri SS. A study on the acute kidney injury in snake bite victims in a tertiary care centre. J Clin Diagnostic Res 2013;7:853-6.

DOI: https://doi.org/10.7860/JCDR/2013/ 5495.2957.

20. Kumar KS, Narayanan S, Udayabhaskaran V, Thulaseedharan NK. Clinical and epidemiologic profile and predictors of outcome of poisonous snake bites - an analysis of 1,500 cases from a tertiary care center in Malabar, North Kerala, India. Int J Gen Med 2018;11:209-16.

DOI: https://doi.org/10.2147/IJGM.S136153.

21. Simpson ID, Norris RL. Snakes of medical importance in India: is the concept of the "Big 4" still relevant and useful? Wilderness Environ Med 2007;18:2-9.

DOI: https://doi.org/10.1580/06-weme-co$023 r 1.1$.

22. Bhalla G, Mhaskar D, Agarwal A. A study of clinical profile of snake bite at a tertiary care centre. Toxicol Int 2014;21:203-8.

DOI: https://doi.org/10.4103/0971-6580.139811.

23. Mallow D, Ludwig D NG. True vipers: natural history and toxinology of Old World vipers. vol. 41. Krieger Publishing Company; 2003.

DOI: https://doi.org/10.5860/choice.41-2177.

24. Tun-Pe, Phillips RE, Warrell DA, Moore RA, Tin-Nu-Swe, Myint-Lwin, et al. Acute and chronic pituitary failure resembling Sheehan's syndrome following bites by Russell's viper in Burma. Lancet (London, England) 1987;2:763-7. 92500-1.

DOI: https://doi.org/10.1016/s0140-6736(87)

25. Fatah C. Pathophysiological and Pharmacological Effects of Snake Venom Components: Molecular Targets. J Clin Toxicol 2014;04.

DOI: https://doi.org/10.4172/2161-0495. 1000190.

This is open access article distributed under the Creative Commons Attribution License, which permits unrestricted use, distribution, and reproduction in any medium, provided the original work is properly cited. 